\title{
GAMBARAN FUNGSI MANAJEMEN DI TAMAN KANAK-KANAK (TK) N
}

Widia Paramita, Weny Savitri S. Pandia

Magister Psikologi Profesi Pendidikan Anak \& Remaja Universitas Katolik Atma Jaya Jakarta widia.paramita@gmail.com,weny_pandia@yahoo.com

\begin{abstract}
Abstrak
Penelitian ini bertujuan untuk mengetahui gambaran fungsi manajemen di TK N (planning, organizing, leading, dan controlling) dan kendala serta upaya yang dilakukan untuk mewujudkannya. Penelitian ini bersifat studi kasus dan mixed-method. Subyek penelitian adalah TK N, yang meliputi kepala TK, guru TK, dan perwakilan yayasan. Pengumpulan data menggunakan kuesioner, wawancara, observasi, dan dokumentasi. Validitas kuantitatif menggunakan teknik content validity dan interrater reliability. Keabsahan data kualitatif menggunakan triangulasi. Data kuantitatif dianalisa menggunakan metode deskriptif persentase, sedangkan data kualitatif dianalisa menggunakan coding dan pendekatan interpretative. Hasil penelitian ini: (1) TK N lebih banyak melakukan fungsi controlling daripada fungsi manajemen lainnya; (2) Kendala yang dihadapi untuk melakukan fungsi manajemen adalah sekolah belum menjabarkan visi ke dalam misi yang jelas, kebijakan dan evaluasi tidak tertulis, kepala TK belum konsisten memberikan teladan, serta agenda kegiatan sekolah yang kurang mencakup kegiatan internal antara kepala TK dan guru. (3) Upaya yang dilakukan sekolah adalah melibatkan perwakilan yayasan dan orang tua siswa dalam melakukan fungsi controlling, pemberian penghargaan teacher of the month dan fasilitas penggantian dana pada para guru mengenai cara mengajar sebagai bentuk fungsi organizing dan leading, serta menyampaikan agenda kegiatan secara lisan pada fungsi planning.
\end{abstract}

Kata kunci: pendidikan anak usia dini, fungsi manajemen

\section{FUNCTION OF MANAGEMENT DESCRIPTION AT TAMAN KANAK-KANAK (TK) $\mathbf{N}$}

Widia Paramita, Weny Savitri S. Pandia

Magister Psikologi Profesi Pendidikan Anak \& Remaja Universitas Katolik Atma Jaya Jakarta widia.paramita@gmail.com,weny_pandia@yahoo.com

\begin{abstract}
This study aimed to determine: (1) description of management function (planning, organizing, leading, and controlling) at TK $N$ and (2) the obstacle and their efforts to actualize these function. This research is case study and mixed-method. The subject is TK N, including the headmaster, teachers, and foundations representative. The data collection used questionnaire, interview, observation, and documentation techniques. The questionnaire validated through content validity and interrater reliability techniques. The interview, observation, and documentation data validation through triangulation. Quantitative data was analysed using descriptive method - percentage. Qualitative data were analysed using coding and interpretative approach. The result of this study: (1) TK $N$ more perform controlling function than the other function. (2) The constraint to perform management functions were school had not yet describe the vision into mission objectively, policies and evaluations are unwritten, headmaster inconsistent gave a good manner, and agenda had not yet include headmaster and teacher internal activities. (3) School have been involved the foundation representative and parents did controlling function, had a teacher of the month appreciation and reimbursement facility for teacher about teaching as part of organizing and leading function, and also delivered the activities agenda unwritten as part of planning function.
\end{abstract}

Keywords: early childhood education, functions of management 



\section{Pendahuluan}

Hoy dan Miskel (2013, p.23) mengungkapkan bahwa sekolah merupakan suatu sistem sosial yang didalamnya terdapat elemen input, proses, dan output. Elemen input meliputi ketersediaan sumber daya manusia, dana, perlengkapan, materi dan metode pembelajaran, serta memiliki misi, kebijakan. Pada elemen proses terdapat struktur, individu, budaya, dan politik. Struktur adalah adanya struktur birokrasi formal di sekolah. Struktur meliputi adanya harapan, peran, dan kebijakan yang dimiliki oleh masing-masing posisi. Struktur birokrasi mengatur jalannya sekolah untuk mencapai tujuan. Individu di sekolah mewakili struktur formal yaitu para sumber daya manusianya. Individu tersebut merupakan gabungan antara dirinya yang memiliki peran dalam suatu struktur dan pribadinya sendiri yang memiliki kebutuhan, keyakinan, dan tujuan. Budaya merupakan hubungan informal yang dinamis antara birokrasi dan individu-individu di dalam sekolah yang kemudian mereka bawa ke dalam sekolah. Politik bersifat informal dan ilegal, bahwa perilaku yang ada di sekolah dapat disesuaikan untuk keuntungan individu atau kelompok. Kemudian pada elemen output, meliputi prestasi, kepuasan kerja, ketidakhadiran, tingginya angka putus sekolah, dan kualitas lain yang dilihat secara keseluruhan.

TK merupakan jalur formal pendidikan anak usia dini (Undang-Undang no. 20 tahun 2003 p.8). TK yang dibahas dalam penelitian ini adalah TK N. Fenomena yang terjadi di TK $\mathrm{N}$ adalah para guru kurang memiliki motivasi untuk bekerja. Kurang motivasi ini dalam pengertian guru yang datang terlambat atau tepat waktu namun menyiapkan diri terlebih dahulu sehingga kurang waktu untuk menyapa siswa yang datang, guru juga kurang dapat mengatur waktunya untuk membuat rekapitulasi penilaian siswa, dan menyusun tugas membuat majalah dinding. Motivasi pada guru terkait dengan motivasi kerja, bukan motivasi mengajar.

Untuk menggali fenomena mengenai motivasi dalam suatu organisasi, peneliti menggunakan kerangka tokoh Porter dan Miles (dalam Steers dan Porter, 1978, p.21) yang meliputi karakteristik individu, pekerjaan, dan lingkungan kerja. Setelah fenomena digali lebih dalam didapat hasil bahwa guru kurang termotivasi menyelesaikan tugas selain mengajar karena beberapa hal, seperti harapan untuk kenaikan gaji, pelatihan untuk mengembangkan kemampuan diri mereka, dan adanya guru untuk mengajar menari dan Iqro, guru juga merasa kurang mendapat umpan balik kerja yang bersifat formal dan kontinu, sekolah kurang terbuka atas ide kegiatan baru, serta adanya kegiatan yang kerap dilakukan mendadak. Dengan adanya fenomena tersebut, sekolah telah melakukan beberapa upaya seperti meningkatkan gaji, menyediakan fasilitas penggantian dana untuk mengikuti pelatihan dan menyetak materi yang dibutuhkan untuk para siswa, serta memiliki sistem penghargaan teacher of the month (TOM) dan ada intensifnya.

Bila TK N dipetakan ke dalam teori Hoy dan Miskel (2013, p.33), maka dapat dilihat bahwa pada elemen input TK $\mathrm{N}$ memiliki sumber daya manusia, dana untuk mengelola kegiatan, visi, misi sekolah, serta metode dan perlengkapan belajar. Pada elemen proses, sekolah memiliki struktur birokrasi untuk mencapai tujuan. Walau sekolah telah memiliki struktur dan yayasan turut andil, namun muncul agenda kegiatan yang mendadak, tugas guru yang kurang tepat waktu selesainya, serta kepala TK juga kurang memotivasi dan memberikan evaluasi kerja yang kontinu pada guru. Individu di sekolah memiliki kebutuhan yang telah diupayakan pemenuhannya oleh sekolah. Dalam hal budaya, TK $N$ merupakan tempat yang menyenangkan bagi guru untuk bekerja dan siswa untuk belajar. Pada segi politik, terjadi saat pemilihan kepala TK yaitu berdasarkan usia dan pengalaman kerja yang dimilikinya. Dalam hal output, kualitas lulusan siswa TK N banyak diterima di SD favorit, guru kurang termotivasi untuk bekerja sehingga kadang kerap datang terlambat dan tidak menyapa siswa di gerbang. Kualitas secara keseluruhan dikhawatirkan dapat 
kurang terjaga bila guru tidak menyelesaikan tugasnya selain mengajar. Dengan adanya pemetaan ini, dapat dikatakan bahwa fenomena yang terjadi di TK $\mathrm{N}$ saat ini merupakan dampak masalah pada elemen proses, terutama pada birokrasi dan individu. Bila dilihat lebih lanjut sekolah telah mengupayakan beberapa hal terkait dengan kebutuhan individu. Oleh karena itu peneliti tertarik mendalami birokrasi yang ada.

Hoy dan Miskel (2013, p.26) menjelaskan bahwa dalam birokrasi ada struktur posisi yang menjalankan sekolah untuk mencapai tujuan. Tokoh Schemerhorn (2013, p.17) dan Sagala (2011, p.50) menambahkan bahwa untuk mencapai tujuan organisasi misalnya sekolah, maka dilakukan fungsi manajemen. Fungsi manajemen yang dibahas adalah fungsi planning, organizing, leading, dan controlling. Fungsi planning meliputi kegiatan memperjelas rencana yang akan dicapai dan langkah yang dapat dicapai. Sekolah melakukan fungsi organizing ketika mereka melakukan pembagian tugas, menentukan anggota yang akan melakukan tugas, serta mengalokasikan dana dan waktu. Fungsi leading dilakukan ketika pemimpin memiliki kemampuan untuk mempengaruhi guru dan karyawan sekolah agar mereka mau bekerja dengan sebaik-baiknya untuk mencapai tujuan sekolah. Sekolah juga melakukan fungsi controlling. Sekolah akan mengumpulkan data dan informasi untuk melihat kembali proses pencapaian tujuan sekolah dan pembelajaran yang ada, termasuk melihat apakah ada penyimpangan atau kekurangan dalam pelaksanaannya.

Fungsi manajemen yang ada di TK N dapat dijelaskan sebagai berikut. Pada fungsi planning, sekolah menggunakan panduan dari pemerintah namun ada beberapa kegiatan yang dilakukan mendadak atau guru yang kurang menyelesaikan tugasnya dengan tepat waktu. Dalam fungsi organizing, kepala TK telah mendelegasikan tugas pada guru dan anggota sekolah lain. Mereka juga berusaha berkoordinasi untuk menyelesaikan tugasnya, namun kepala TK cenderung mempercayakan kegiatan pada para guru. Dalam fungsi leading, guru telah berusaha meningkatkan motivasi siswa agar mereka dapat bekerja dengan optimal untuk mencapai tujuan, namun kepala TK dirasa kurang memberikan motivasi pada para guru dan kurang terbuka atas ide kegiatan baru. Fungsi controlling telah cukup dilakukan untuk melakukan pengukuran kinerja siswa dan melakukan tindakan untuk meningkatkannya, serta pengukuran kinerja guru. Akan tetapi, rekapitulasi kinerja siswa cenderung kurang optimal karena dilakukan menjelang pembagian rapor sehingga diperkirakan tindakan perbaikan menjadi kurang optimal bagi siswa. Pengukuran kinerja guru juga telah dilakukan namun kurang optimal karena peran ganda yang dimiliki oleh kepala TK. Dengan demikian dapat dikatakan sementara bahwa sekolah belum melakukan fungsi manajemen dengan optimal.

Pada Peraturan Pemerintah (PP) no. 66 tahun 2010 mengenai pengelolaan dan penyelenggaraan pendidikan tertulis bahwa dalam satuan pendidikan anak usia dini jalur formal, yang diselenggarakan pemerintah atau daerah memiliki paling sedikit kepala sekolah yang menjalankan fungsi manajemen dan komite sekolah yang menjalankan fungsi pengarahan, pertimbangan, dan pengawasan akademik. Fungsi manajemen dalam ranah pendidikan digunakan dalam konsep Manajemen Berbasis Sekolah (MBS) yang penerapannya di Indonesia mengacu pada Peraturan Menteri Pendidikan Nasional (Permendiknas) no. 19 tahun 2007 (Suparlan, 2013, p.63). Dengan adanya konsep baku tersebut maka untuk melihat fungsi manajemen di TK $\mathrm{N}$, peneliti menggunakan pendekatan MBS.

MBS merupakan suatu konsep yang sering digunakan untuk menelaah manajemen sekolah. Suparlan (2013, p.42) menjelaskan bahwa MBS dilatarbelakangi oleh pemikiran untuk mencapai tujuan sekolah ada empat fungsi manajemen yang harus dilakukan yaitu perencanaan, pengorganisasian, pengarahan, dan pengontrolan. MBS memiliki tiga pilar yaitu manajemen sekolah, pembelajaran yang aktif, kreatif, efektif, dan menyenangkan, serta adanya 
peran serta masyarakat (Pemerintah Indonesia, Unicef, dan Unesco, 2009, p. 4).

MBS mengatur beberapa hal sedangkan TK N memiliki beberapa karakteristik, maka panduan MBS yang digunakan dalam penelitian disesuaikan dengan karakteristik yang ada. Karakteristik yang ada yaitu budaya sekolah berasaskan pendidikan agama Islam, kebijakan keuangan dipegang oleh yayasan, dan tidak ada komite sekolah formal, sehingga pembatasan ruang lingkup konsep MBS dalam penelitian ini adalah tidak mengikutsertakan manajemen keuangan dan budaya sekolah. Oleh karena itu penelitian ini tidak dapat dikatakan sebagai penerapan MBS di TK N. Adapun pilar-pilar MBS secara tidak langsung dilihat dalam konteks TK N.

Beberapa penelitian mengenai fungsi manajemen dalam lingkup pendidikan Indonesia, seperti telaah fungsi-fungsi manajemen dalam pendidikan Islam (Ainurrofiq dalam Misra dan Maria, 2013, p.433) dan manajemen pendidikan di PAUD Al-Fath Sabang (Bustami, Murniati, dan Harun, 2012, p.5). Penelitian mengenai manajemen sekolah lainnya juga menemukan bahwa kepala Madrasah yang menerapkan fungsi manajemen dapat mengembangkan profesionalitas guru (Wahyudi, 2010) dan dapat membuat guru SMP bekerja sesuai tugas dan tanggung jawabnya (Syaroni, 2006, p.76). Guru merupakan kunci utama dalam keberhasilan dan peningkatan mutu pendidikan (Yudhawati, 2014, p.26). Begitu pula dengan hasil penelitian yang dilakukan oleh Hartanti dan Sarno (2010, p.66) bahwa penerapan fungsi manajemen yang meliputi perencanaan, pengorganisasian, pelaksanaan, dan evaluasi, saling terkait dan mendukung pelaksanaan PAUD. Beberapa penelitian tersebut memperlihatkan bahwa fungsi manajemen merupakan hal penting dalam menjalankan suatu sekolah.

Penelitian ini penting untuk dilakukan karena adanya masalah dalam birokrasi terutama dampak bila fungsi manajemen yang belum diatasi, agar sekolah dapat meningkatkan kinerjanya, serta belum ada penelitian serupa di TK N. Dampak pada fungsi planning misalnya motivasi kerja guru yang menurun karena ada kegiatan-kegiatan mendadak, dan mempengaruhi kualitas belajar siswa. Fungsi ini terkait pula dengan fungsi organizing, bahwa tugas membuat perencanaan mengajar diserahkan pada guru saja sehingga kurang ada pengorganisasian yang sistematis. Sekolah juga kurang memberikan motivasi pada guru yang berhubungan dengan fungsi leading. Guru juga merasa kurang puas akan penilaian pada fungsi controlling, dan dapat berdampak pada motivasi kerja mereka. Oleh karena itu pelaksanaan, kendala yang dihadapi, serta upaya yang telah dilakukan di TK $\mathrm{N}$ untuk mewujudkan pelaksanaan fungsi manajemen perlu dilihat lebih lanjut agar pelaksanaan kegiatan sekolah dapat berjalan lebih baik. Dari sisi psikologis dapat diharapkan bila sekolah memiliki pengetahuan akan peran dan batasan yang jelas mengenai fungsifungsi yang dapat dilakukan maka mereka akan belajar memantau kinerja dan perilakunya mendatang.

\section{Metode Penelitian}

Jenis, Tempat, Waktu dan Subjek Penelitian

Penelitian ini bersifat studi kasus. Jenis penelitian ini memungkinkan peneliti untuk mengumpulkan informasi mengenai kejadian atau kelompok tertentu (Berg, 2007, p.293). Penelitian ini dirancang untuk memahami fenomena yang ada di TK N. Perolehan data dalam penelitian didapat dengan pendekatan kuantitatif dan kualitatif.

Penelitian ini dilakukan di TK N. Penelitian dilakukan pada tanggal 14-28 April 2015. Partisipan penelitian adalah kepala TK, guru TK, dan perwakilan yayasan yang kerap berada di sekolah. Partisipan dipilih dengan metode purposive sampling agar di dapat data penelitian yang menyeluruh.

\section{Prosedur}

Pada tahap perencanaan, peneliti mengunjungi TK $\mathrm{N}$ dan meminta ijin kepada kepala sekolah dan perwakilan yayasan untuk melakukan penelitian. Setelah mendapat ijin maka peneliti melakukan wa- 
wancara awal pada perwakilan yayasan dan beberapa guru. Dari hasil wawancara, kemudian peneliti memperdalam fenomena mengenai masalah motivasi kerja melalui wawancara dengan kepala TK dan wawancara kelompok dengan guru. Adapun wawancara dengan kepala TK baru dapat dilaksanakan karena kesibukan beliau dan libur sekolah. Setelah mendapatkan gambaran fenomena yang lebih mendalam, kemudian peneliti merumuskan tujuan dan panduan penelitian.

Pada tahap pelaksanaan, peneliti menyebarkan kuesioner pada kepala dan guru TK, serta perwakilan yayasan. Peneliti memiliki kesempatan untuk menjelaskan pernyataan kuesioner pada partisipan di waktu yang berbeda. Peneliti dapat melakukan observasi kegiatan sekolah di jeda waktu antara penyebaran dan pengumpulan kuesioner. Setelah peneliti mendapatkan data, peneliti langsung mengolahnya dan menjadi panduan tambahan untuk wawancara dan dokumentasi.

Data, Intrumen, dan Teknik Pengumpulan Data

Pendekatan kuantitatif dilakukan dengan menggunakan instrumen kuesioner. Kuesioner disusun berdasarkan MBS dan dikategorikan ke dalam fungsi manajemen serta disesuaikan dengan karakteristik di TK N. Pembagian pernyataan kuesioner berdasarkan fungsi manajemen disajikan pada Tabel 1.

Tabel 1. Pembagian Pernyataan Kuesioner Berdasarkan Fungsi Manajemen

\begin{tabular}{lc}
\hline Fungsi manajemen & Jumlah pernyataan \\
\hline Fungsi planning & 14 \\
Fungsi organizing & 33 \\
Fungsi leading & 6 \\
Fungsi controlling & 17 \\
\hline
\end{tabular}

Setiap fungsi manajemen akan dihitung persentasenya. Ketentuan perhitungan persentase dilakukan dengan cara: (1) setiap pernyataan bernilai (bobot skor) 5 . Bobot skor 5 diberikan dengan mempertimbangkan bahwa setiap partisipan penelitian memberikan penilaiannya; (2) setiap fungsi akan memiliki nilai skor dan total skor; (3) skor di dapat dari jumlah jawaban partisipan penelitian. Total skor di dapat dari jumlah pernyataan di kali 5 (bobot skor); (4) persentase setiap fungsi manajemen:

$$
\frac{\text { skor }}{\text { total skor }} \times 100 \%
$$

Dari persentase yang di dapat, dapat dikatakan bahwa: (1) semakin banyak kegiatan perencanaan yang dilakukan di TK N, maka semakin besar persentase fungsi planning yang dilakukan; (2) semakin banyak kegiatan pengorganisasian yang dilakukan di TK N, maka semakin besar persentase fungsi organizing yang dilakukan; (3) semakin banyak kegiatan mengarahkan atau memimpin yang dilakukan di TK $\mathrm{N}$ maka semakin besar persentase fungsi leading yang dilakukan; (4) semakin banyak kegiatan mengevaluasi yang dilakukan di TK $\mathrm{N}$, maka semakin besar persentase fungsi controlling yang dilakukan.

Pendekatan penelitian kualitatif dilakukan melalui wawancara, observasi, dan dokumentasi. Panduan wawancara, observasi, dan dokumentasi juga berdasarkan MBS dan teori fungsi manajemen serta disesuaikan dengan karakteristik di TK N. Panduan pertanyaan fungsi manajemen yang diajukan dalam wawancara merupakan pengembangan dari kuesioner yang meliputi kendala pelaksanaan, upaya yang telah dilakukan, dan hasilnya. Panduan observasi meliputi observasi kegiatan sekolah. Dokumentasi meliputi agenda sekolah, RKH/RKM, dan agenda TK N.

Validitas penelitian kuantitatif dilakukan oleh expert. Adanya expert merupakan prosedur di dalam content validity (Crocker \& Algina, 1986, p. 218). Reliabilitas data kuantitatif didapat dilakukan dengan metode interrater reliability. Dari hasil tersebut di dapat data skor tiap fungsi manajemen yang telah dilakukan oleh sekolah. Sedangkan kredibilitas penelitian kualitatif adalah dengan meminimalkan bias dari pemeriksa. Patton (2006, p.556) mengatakan bahwa triangulasi dapat menambah kredibilitas kesimpulan yang di dapat. 
Data kuantitatif dan kualitatif yang telah diperoleh dapat memberikan gambaran yang komprehensif mengenai fungsi manajemen yang dilakukan di TK $\mathrm{N}$.

\section{Teknik Analisis Data}

Teknik analisa data yang digunakan dalam penelitian kuantitatif adalah metode deskriptif persentase. Teknik analisa data yang digunakan dalam penelitian kualitatif adalah metode coding dan pendekatan interpretative. Pendekatan interpretative memperbolehkan peneliti untuk melakukan analisa terhadap hasil wawancara dan observasi (Berg, 2007, p.304).

\section{Hasil Penelitian dan Pembahasan}

Gambaran tenaga pendidik TK N sebagai berikut. Kepala TK $\mathrm{N}$ merupakan tenaga pendidik senior bila dibandingkan dengan para guru. Kepala TK berpendidikan akhir PGTK dan akademi sekretaris. Beliau telah bekerja sejak TK $\mathrm{N}$ berdiri. Para guru TK ada yang berpendidikan akhir S1 PAUD dan PGTK. Guru dengan pendidikan akhir PGTK tengah melanjutkan studi S1 PAUD. Para guru rata-rata adalah lulusan baru, walau ada yang telah berpengalaman satu tahun sebagai guru TK A.

Dari hasil kuesioner yang telah diisi oleh para partisipan, di dapat hasil persentase tiap fungsi manajemen yang ada. Hasil perhitungan skor tiap fungsi manajemen disajikan pada Tabel 2 .

Tabel 2. Perhitungan Skor Fungsi Manajemen

\begin{tabular}{lc}
\hline Fungsi manajemen & Persentase \\
\hline Fungsi planning & 61,43 \\
Fungsi organizing & 66,06 \\
Fungsi leading & 63,33 \\
Fungsi controlling & 75,29 \\
\hline
\end{tabular}

Berdasarkan tabel di atas menunjukkan bahwa fungsi controlling adalah fungsi manajemen yang paling banyak dilakukan di TK $\mathrm{N}$, terutama bila dibandingkan dengan fungsi planning. Adapun skor fungsi organizing, leading, dan planning tidak jauh berbeda.
Dari hasil wawancara, observasi, dan dokumentasi, dapat dilihat bahwa sekolah melakukan fungsi controlling pada siswa berdasarkan panduan kurikulum pemerintah dan terhadap kinerja guru. Fungsi ini dilakukan oleh kepala TK dan yayasan. Orang tua juga dapat melakukan fungsi ini melalui buku penghubung. Hasil fungsi controlling adalah laporan perkembangan siswa, rapor, penghargaan serta sanksi bagi guru. Akan tetapi upaya melakukan fungsi controlling dalam hal mengevaluasi kegiatan selain belajar-mengajar baru dilakukan dalam bentuk pembahasan non-formal, belum ada indikator sehingga tidak ada laporan tertulis tahunan.

Rapat tidak resmi (NM/24/5/2015).

Tidak ada formal, rapat, atau tertulis (AN/24/4/2015).

Kendala dalam melakukan fungsi controlling peran rangkap kepala TK dan guru yang belum konsisten menyelesaikan tugas administratifnya.

Sebenarnya kalau saya bisa melihat di kelas, penilaian jadi bisa lebih baik. ... Guru perlu diingatkan dulu baru jalan. Kalau saya bilang tanggal segitu mengumpulkan lalu saya sedang ada tugas keluar atau lupa, ya sudah itu guru tidak kasih ke saya (NM/24/4/2015).

Dari evaluasi yang ada belum ada tindak lanjutnya karena belum ada aturan dan agenda kerja yang terstruktur.

Berhubung kepala sekolah belum memiliki ketetapan jadinya kerja kurang terarah. Kalau sudah ada ketetapan, kerja bisa lebih terarah, guru tidak bisa semaunya (RS/27/4/2015).

Sekolah melakukan fungsi organizing dalam menyiapkan dan melakukan penilaian pada siswa. Kepala TK mengorganisir guru untuk memikirkan kompetensi siswa sesuai kurikulum yang digunakan dan staf tata usaha yang menyiapkan lampirannya. Sekolah memiliki petunjuk tidak formal mengenai mekanisme penyampaian siswa dan orang tua siswa pada pihak sekolah. Petunjuk ini secara tidak langsung ditetapkan oleh kepala TK bersama yaya- 
san. Hal ini telah dipahami oleh guru dan dirasa membantu.

Hasilnya tidak ada komplain. Tidak ada kendala karena ada tim psikolog. Patokan kami kalau ada kritik untuk mawas diri (HV/24/5/2015).

Sekolah juga melakukan analisa faktor kekuatan, kelemahan, tantangan, dan peluang yang dimiliki. Sayangnya analisa faktor-faktor tersebut juga belum dibuat rekapitulasinya.

Pada fungsi leading, pada dasarnya sekolah telah melakukan komunikasi untuk menciptakan dukungan dari orang tua siswa seperti melalui buku penghubung dan rapat untuk persiapan kegiatan. Sekolah juga melakukan komunikasi dengan masyarakat dalam arti masyarakat yang terkait dengan program, belum dengan masyarakat sekitar sekolah.

Belum ada dengan masyarakat sekitar, belum ada program. Kalau dengan pihak lain misalnya field trip tiap tahun. Field trip tiap tahun ajaran baru. Ada rapat dengan orang tua. Duduk sama-sama, mengingatkan. (NM/24/4/2015).

Sekolah juga telah menjaga dengan baik lembaga, profesi, dan kedudukannya. Walau demikian, kepala TK belum konsisten memberikan teladan yang bertanggung jawab.

Loyal, tidak menjelekkan nama sekolah, menjembatani yayasan dan guru. Tapi tidak selalu memberi contoh, misalnya kadang makan di kantor padahal sudah ada ruang makan. Kadang terlambat kadang tidak kasih kabar ke yayasan (HV/24/5/2015).

Sekolah memiliki kebijakan mengenai anggaran. Kebijakan tersebut yaitu kepala TK bertanggung jawab terhadap anggaran harian sedangkan yayasan terhadap anggaran program. Pengembangan guru saat ini cenderung lebih kepada kebutuhan kurikulum, kurang mengakomodir aspirasi guru.

Waktu itu saya pernah punya ide tentang market day tapi jadinya cooking day saja (AN/24/4/2015).
Ide market day tidak dibolehkan karena nanti ibu guru repot. Maksudnya ibu guru anak-anak sudah masak, jadi sekalian pura-pura dijual terus orangtuanya beli. Masih ada waktu kalau mau dilakukan. Kita selesai masak jam 10, pulang jam 11 (RS/27/5/2015).

Dalam fungsi planning, sekolah telah telah memiliki visi dan misi. Visi dan misi pertama kali disusun oleh yayasan. Sekolah terbuka atas masukan terkait dengan visi dan misi tersebut. Sekolah berupaya mensosialisasikan visi dan misi dengan cara memasang spanduk di sekolah. Akan tetapi visi dan misi kurang dipahami oleh guru.

Untuk membawa anak lebih cerdas, kreatif, agamanya baik. Tidak tahu pasti, padahal ada di depan (ML/24/4/2015).

Menghasilkan anak yang berakhlak baik, budi pekerti. Visinya memiliki pengetahuan yang lebih luas. Sebacanya saya di depan (AN/24/4/2015).

Sekolah telah menyusun program dan ketentuan penilaian hasil belajar berdasarkan standar penilaian pendidikan. Sekolah juga bertanggung jawab atas perencanaan partisipatif mengenai pelaksanaan kurikulum dan membuat rencana kerja tahunan untuk pelaksanaan peningkatan mutu.

Di awal tahun, buat RKH/RKM sesuai pemerintah. Rencana kerja tahunan berdasarkan kalender diknas (RS/27/4/2015).

Sekolah telah menyusun prioritas indikator untuk mengukur kinerja guru namun pengukuran terhadap kinerja sekolah belum dipahami oleh guru karena belum konsisten dilakukan dan disampaikan oleh kepala TK. Adapun indikator tersebut disusun oleh kepala TK dan yayasan.

Walau beberapa hal telah dilakukan oleh sekolah, namun sekolah belum menjabarkan visi ke dalam misi target mutu dan membuat rencana kerja strategis untuk meningkatkan mutu sekolah. Dalam hal ini tugas tersebut merupakan tanggung jawab kepala TK.

Belum, belum ada gambaran. Sudah lama tapi tidak ditulis, dari mulut ke mulut, 
tidak dilakukan karena beranggapan ibu guru sudah tahu (NM/24/4/2015).

Yayasan belum mengetahui apakah kepala TK menjabarkan visi ke dalam misi target mutu. Kepala TK sudah merumuskan tujuan dan target mutu yang akan dicapai tapi tidak secara tertulis (HV/24/4/2015).

Selain itu ada faktor luar sekolah yang turut mempengaruhi fungsi planning yaitu kegiatan yang kerap dilakukan mendadak oleh pemerintah sehingga dapat mengganggu jadwal kegiatan di sekolah.

Dari hasil penelitian tersebut, menunjukkan bahwa TK N melibatkan kepala TK, guru, staf, dan yayasan untuk menjalankan kegiatan sehari-hari. Sekolah juga melibatkan orang tua dan organisasi luar terkait untuk mencapai tujuan sekolah. Kepala TK dan guru memiliki beberapa peran, kebijakan, dan tanggung jawab. Hal ini cukup menggambarkan teori Hoy dan Miskel (2013, p.23) yang menyebutkan sekolah sebagai suatu sistem sosial. Hoy dan Miskel (2013, p.32) menambahkan bahwa sistem sekolah memiliki umpan balik internal dan eksternal. TK $\mathrm{N}$ melakukan umpan balik internal dengan melibatkan kepala TK, guru, dan yayasan, dan eksternal yang dilakukan oleh orang tua. TK $\mathrm{N}$ juga melakukan kegiatannya berdasarkan sistem pemerintah yaitu memperhatikan sumber daya guru, sarana-prasarana, dan kurikulum. Hal ini sejalan dengan Petunjuk Teknis Penyelenggaraan TK (Direktorat Pembinaan PAUD, 2011).

Pada konteks sekolah sebagai suatu organisasi yang menjalankan perannya secara tidak langsung melaksanakan fungsi manajemen. Hasil penelitian di TK $\mathrm{N}$ yang dapat diapresiasi adalah dengan adanya beberapa fungsi manajemen yang diterapkan oleh Kepala TK dan guru membuat mereka dapat bekerja sesuai tugas dan tanggung jawab, serta mendukung pelaksanaan kegiatan. Hal ini sejalan dengan penelitian yang dilakukan oleh Syaroni (2006, p.76) serta Hartanti dan Sarno (2010, p.66). Dari penelitian yang dilakukan oleh Wahyudi (2010) dikatakan bahwa kepala sekolah yang menerapkan fungsi manajemen dapat mengembangkan profesiona- litas guru. Akan tetapi bila ditilik kembali pada hasil penelitian di TK $\mathrm{N}$ dapat dilihat bahwa pelaksanaan fungsi manajemen yang dilakukan oleh kepala TK belum optimal. Kepala TK kurang optimal dalam melaksanakan fungsi manajemen disebabkan oleh peran rangkapnya sebagai guru TK B dan pribadinya yang belum konsisten melakukannya. Keadaan ini dapat berdampak pada kurang berkembangnya profesionalitas guru yang tampak pada perilaku kurang disiplin. Selain itu, walau fungsi manajemen telah dilakukan tetapi guru kurang mengetahui adanya kesinambungan beberapa pihak yang terkait, atau kepala TK yang mengetahui fungsinya namun belum konsisten melaksanakannya.

Fungsi manajemen controlling yang lebih banyak dilakukan dan fungsi planning kurang dilakukan di TK $\mathrm{N}$ menggambarkan bahwa fungsi manajemen yang ada kurang berjalan dengan baik. Hal ini sesuai dengan Schemerhorn (2013, p.20) bahwa ketika melakukan fungsi manajemen, berawal dari kematangan fungsi planning. Oleh karena itu fungsi planning perlu diubah dan sekolah memulai kembali melakukan aktivitas dan fungsi manajemen selanjutnya.

Hoy dan Miskel (2013, p.27) menambahkan bahwa apa yang seseorang lakukan dalam pekerjaannya akan mengarah pada memantau dan mengevaluasi perilakunya. Dalam hal ini dapat diperkirakan bahwa kepala TK dan guru kurang memahami pekerjaannya sehingga kurang ada yang belum diketahui dan dilaksanakannya. Mereka juga kurang melakukan pemantauan dan pengevaluasian diri sendiri walau memiliki tanggung jawab dan tenggat waktu penyelesaian.

Dari sisi guru ditemukan bahwa pada dasarnya mereka paham dan bersedia melakukan fungsinya. Akan tetapi karena kurangnya kejelasan sistem, penghargaan yang bersifat personal khususnya dari kepala TK dan sistem TOM, serta sanksi yang belum jelas maka mereka kurang optimal saat melaksanakannya. Guru juga tampak kurang memahami istilah seperti diagnostik, formatif, dan sumatif. Ketika 
dijelaskan mereka paham bahwa mereka telah melakukannya. Dari keadaan ini dapat diperkirakan bahwa faktor latar belakang pendidikan berpengaruh yaitu bahwa pendidikan guru terdahulu mengutamakan praktik kerja daripada mengetahui latar belakang teori yang mendasarinya.

Kendala kurangnya pengetahuan dan pemahaman yang dihadapi kepala TK dan guru dapat dikaitkan dengan teori Bloom. Bloom (dalam Crocker \& Algina, 1986, p.73) menyebutkan bahwa tahap pengetahuan merupakan tahap dasar dan tujuan dari tahap ini misalnya dapat menyebutkan visi misi sekolah atau tugas sebagai kepala TK dan guru. Tahap pemahaman merupakan tahap selanjutnya. Di sini proses pemaknaan konsep yang dapat dilakukan di situasi yang berbeda misalnya tugas sebagai kepala TK dan guru khususnya pemahaman interaksi kerja sama dengan melihat karakteristik di TK N. Mengacu pada teori Bloom di atas maka terlihat bahwa tahapan dasar pengetahuan mengenai visi misi dan tugas-tugas merupakan hal yang penting untuk diketahui oleh kepala TK dan guru.

\section{Simpulan dan Saran}

Simpulan

Kesimpulan dari hasil penelitian ini adalah sebagai berikut. Pertama, fungsi controlling merupakan fungsi manajemen yang lebih banyak dilakukan di TK N. Kepala TK dan guru memiliki indikator untuk melakukan controlling terhadap kinerja siswa. Yayasan dan kepala TK juga memiliki indikator terhadap kinerja guru. Sekolah melibatkan peran perwakilan yayasan yang kerap berada di sekolah dan orang tua untuk melakukan controlling terhadap kinerja guru. Akan tetapi kepala TK kurang optimal melakukan fungsi controlling karena peran rangkap yang dimilikinya. Evaluasi hasil belajar saat ini belum dilaksanakan dengan konsisten karena belum ada aturan tenggat waktu. Walau kepala TK dan guru telah melakukan evaluasi pertanggungjawaban satu tahun kegiatan pada pihak yayasan namun belum dilakukan dalam bentuk laporan tertulis.
Kedua, Fungsi planning merupakan fungsi manajemen yang kurang dilakukan di TK N. Kepala TK telah bertanggung jawab atas perencanaan pelaksanaan kurikulum dan rencana kerja tahunan. Dalam hal visi misi, walau sekolah telah memiliki visi dan misi sekolah namun hal ini kurang dipahami oleh guru. Kepala TK tampak belum menjabarkan visi ke dalam misi yang berdasarkan target mutu dan membuat rencana kerja strategisnya setidaknya untuk lima tahun mendatang. Kepala TK dan yayasan telah menyusun prioritas indikator namun belum konsisten dilakukan dan disampaikan oleh kepala TK. Adapun ada kendala dari faktor luar sekolah yang dapat mempengaruhi fungsi planning yaitu kegiatan yang kerap dilakukan mendadak oleh pemerintah sehingga dapat mengganggu jadwal kegiatan di sekolah.

Saran

Saran yang dapat diberikan untuk penelitian selanjutnya seperti saat mengambil data sebaiknya mempertimbangkan agenda kegiatan sekolah agar partisipan memiliki lebih banyak waktu untuk memahami dan mengisi kuesioner walau partisipan telah mendapatkan penjelasan mengenai pernyataan, mengikutsertakan staf administrasi dalam penelitian, menambah atau mengurangi pertanyaan khususnya pada fungsi yang kurang berimbang jumlahnya dalam penelitian ini, serta melakukan evaluasi terhadap program psikoedukasi yang dirancang oleh peneliti.

Saran praktis yang dapat dilakukan (1) sekolah memiliki agenda sekolah yang meliputi penetapan tanggal atau minggu pengumpulan penilaian. Langkah ini dapat digunakan selanjutnya sebagai kriteria penilaian yang jelas; (2) Evaluasi kinerja pada kepala TK dan guru dapat dilakukan dengan melibatkan penilaian antarpihak. Nilai akhir penilaian kinerja diperoleh dari nilai rata-rata. Antarpihak pun perlu mengetahui makna kriteria dan angka penilaiannya; (3) sekolah mulai perlu membuat laporan kegiatan tertulis, yang mencakup bentuk kegiatan, kendala yang ditemui, dan hasil yang didapat; (4) sekolah mem- 
berikan kesempatan berkala pada anggota sekolah, terutama pada para guru untuk menyumbangkan ide secara tertulis dalam suatu wadah dan dimungkinkan anonim; (5) sekolah mendapatkan psikoedukasi mengenai fungsi manajemen yang dilakukan di sekolah dan keterkaitan antaranggota sekolah ketika menjalankannya dalam konteks sekolah sebagai suatu sistem. (6) sekolah dapat menyiapkan seorang guru yang akan meneruskan pemahaman ini, terutama dengan mempertimbangkan perbedaan masa kerja kepala TK dan para guru.

\section{Daftar Pustaka}

Berg, B. (2007). Qualitative Research : Methods for the Social Sciences. (6thed.). Boston: Pearson Education, Inc.

Bustami, Murniati, \& Cut, Z.H. (2012). Manajemen pendidikan paud alfath sabang. Jurnal Administrasi Pendidikan Pascasarjana Universitas Syiah Kuala, Vol. 1, no. 2: 1-12.

Crocker, L. \& Algina, J. (1986). Introduction to classical and modern test theory. Florida: Harcourt Brace Jovanovich College.

Direktorat Pembinaan PAUD. (2011). Petunjuk Teknis Penyelenggaraan TK. Kementerian Pendidikan Nasional.

Hartanti dan Sarno. (2010). Manajemen pendidikan anak usia dini (PAUD) di kota Yogyakarta. Jurnal penelitian Bappeda kota Yogyakarta vol. 5 no. 5; 63 - 69. Yogyakarta: Bappeda Pemerintah Kota Yogyakarta.

Hoy, K.W. \& Miskel, C.G. (2013). Educational administration (9thed.). Singapore: McGraw-Hill Education (Asia).

Misra \& Maria, R. (2013). Pelaksanaan manajemen berbasis sekolah (mbs) di mtsn batusangkar. Al-Ta'lim, No. $5 ; 431-444$.

Patton, M. (2002). Qualitative Research and Evaluation Methods. (5 ${ }^{\text {thed.). }}$. California: Sage Publications, Inc.

Pemerintah Indonesia, Unicef, dan Unesco. (2009). Program manajemen berbasis sekolah: konsep pelaksanaan, peren- canaan, monitoring, evaluasi, dan supervisi. Diakses tanggal 27 Maret 2015 dari http://mbscenter.or.id/ sources/14FA\%20Book\%202.pdf

Peraturan Pemerintah no. 66 tahun 2010. Pengelolaan dan penyelenggaraan pendidikan. Diakses tanggal 7 April 2015 dari http://www.unpad.ac. id/wp-content/uploads/2012/10/ PP66-2010-

PengeloaanDanPenyelenggaraanPe ndidikan.pdf

Sagala, S. (2011). Kemampuan profesional guru dan tenaga kependidikan. Bandung: Alfabeta.

Schemerhorn, J. (2013). Introduction to management (12thed.). Singapore: John Wiley \& Sons.

Steers, R. M. dan Porter, L. W. (1987). Motivation and work behavior. New York: McGraw-Hill.

Suparlan. (2013). Manajemen berbasis sekolah dari teori sampai dengan praktik. Jakarta: Bumi Aksara.

Syaroni. (2007). Pengaruh kinerja kepemimpinan dan manajemen kepala sekolah terhadap kinerja guru smp negeri di kabupaten brebes. Tesis. Universitas Negeri Semarang. Diakses tanggal 17 Februari 2015 dari http:/ / lib.unnes.ac.id/16729/1/110 3505086.pdf.

Undang-Undang no. 20 tahun 2003. Diakses tanggal 7 Mei 2015 dari http: // kemenag.go.id/file/dokumen/U U2003.pdf

Wahyudi, I. (2010). Peran kepala madrasah dalam mengembangkan profesionalitas guru (studi penerapan fungsi manajemen kepala madrasah di sekolah alam bilingual mts surya buana malang). Tugas Akhir. Universitas Islam Negeri. Diakses tanggal 17 Februari 2015 dari http://lib. uin-malang.ac.id/? $\bmod =$ th detail\&id=07920006.

Yudhawati, S. (2014). Manajemen sdm dalam pembelajaran pendidikan anak usia dini di tk angkasa lanud iswahjudi maospati magetan. Jurnal Ilmiah Pendidikan vol. 2 no. 1; $24-32$. 